\title{
THE IMPACT OF ISLAMIC MONETARY OPERATIONS AND AGGREGATE FINANCING ON ECONOMIC GROWTH IN INDONESIA (2010-2020)
}

\author{
Adinda Madani ${ }^{\mathrm{a}}$ \\ Tika Widiastuti ${ }^{\text {b }}$ \\ a,bIslamic Economics Department, Faculty of Economics and Business, University of Airlangga \\ Email: adinda.madani-2017@feb.unair.ac.id ${ }^{a}$; tika.widiastuti@feb.unair.ac.id ${ }^{b}$
}

ARTICLE HISTORY

Received:

25 March 2021

Revised

16 September 2021

Accepted:

26 November 2021

Online available:

30 November 2021

Keywords:

Bank Indonesia Sharia

Certificate,

Bank Indonesia Syariah

Deposit Facility,

Sharia Interbank

Money Market,

Aggregate Financing,

Economic Growth.

* Correspondence:

Name: Tika Widiastuti

E-mail:

tika.widiastuti@feb.un

air.ac.id

\section{ABSTRACT}

Islamic monetary operation policies are regulated to increase the effectiveness in facing economic developments, especially the monetary sector. The working mechanism of the Islamic monetary operation up to its impact on the development of the national economy illustrates the monetary policy transmission carried out by Bank Indonesia. The purpose of this study is to analyze the effects of Bank Indonesia Sharia Certificate (SBIS), Bank Indonesia Sharia Deposit Facility (FASBIS), Sharia Interbank Money Market (PUAS), and aggregate financing on Indonesia's economic growth in the period 2010 to 2020. This research method uses a quantitative approach with the analysis technique Vector Auto Regression (VAR) or Vector Error Correction Model (VECM) to see the long-term impact and shock response on certain variables. Using secondary data on the variables, it is obtained from the Indonesian Economic and Financial Statistics Bank Indonesia (SEKI-BI) and the Central Statistics Agency (BPS) for the period January 2010 to December 2020. This study found that the SBIS variable has a negative relationship with GDP. Meanwhile, the variables FASBIS, PUAS, and aggregate financing have a positive relationship with GDP. For the future, it can be used as input and consideration in policy making that will be determined in optimizing Islamic monetary policy in Indonesia. Further research that will discuss this topic should use Islamic monetary instruments that are more complete than Islamic open market operations and sharia standing facilities. As well as comparing with conventional monetary operation instruments as a comparison for Islamic monetary.

\section{INTRODUCTION}

Indonesia as a developing country, development and economic growth are the main instruments to achieve national goals to reduce unemployment and create inflation stabilization (Naf'an, 2014). One of the macroeconomic indicators of a country is measured from the projected economic growth through the total value of the gross domestic product (GDP). The high value of GDP indicates that the country's economic 
growth conditions are good. Therefore, the country strives to achieve an optimal level of economic growth with various policies taken in the economy, one of which is through monetary policy (Twinoburyo \& Odhiambo, 2018).

Today's economy has entered a phase of instability. To overcome this problem of instability, a monetary policy is required by Bank Indonesia as the central bank of the Indonesian state. The stability of the Indonesian economy can be seen from the growth of the Indonesian economy. According to the report of Central Bureau of Statistics (BPS), Indonesia's economic growth tends to decline in the last ten years. The following is a graph of Indonesia's economic growth rate as measured by the projection of Gross Domestic Product (GDP) growth in the period 2010 to 2020.

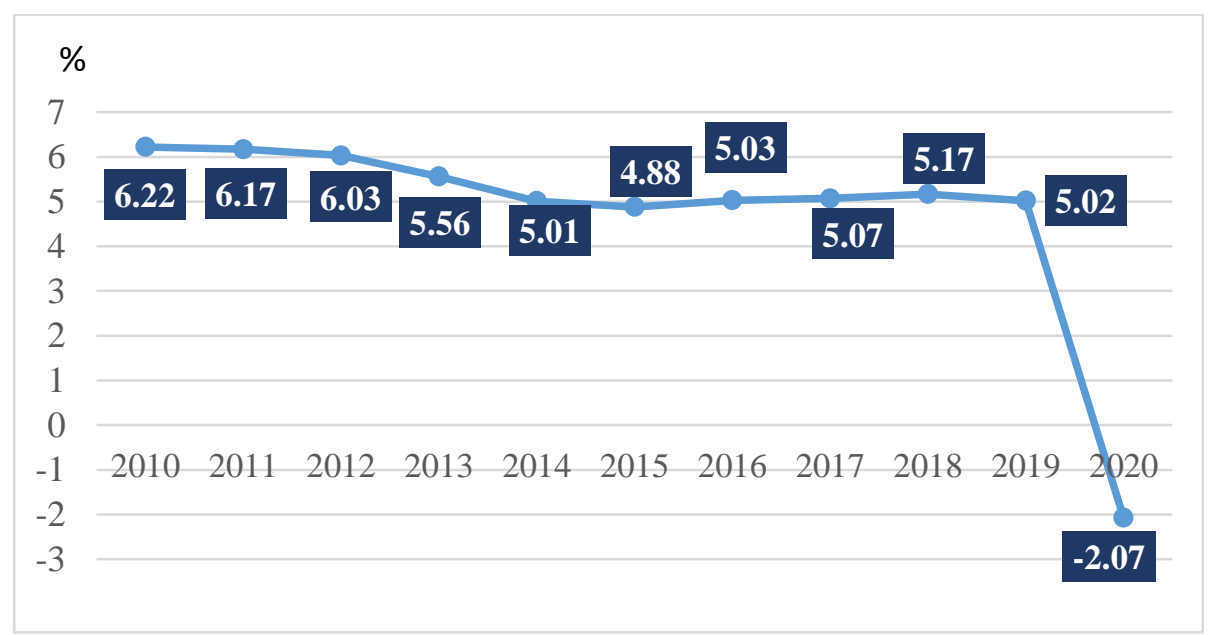

Figure 1 Indonesia's Economic Growth (in percentage)

Source: Processed Data (Central Bureau of Statistics, 2020)

Monetary policy is implemented by Bank Indonesia as the central bank of Indonesia which functions as the executing authority of the Indonesian monetary authority. In Indonesia, two monetary policy systems are enforced, namely conventional monetary and Islamic monetary. In conventional monetary, making the relationship between money and interest an important variable in determining conventional monetary policy instruments is different from Islamic monetary. One of the main principles and provisions of sharia in the Islamic economic system is the prohibition of usury. When viewed from market rationality, usury has the same characteristics as interest (Juhro et al., 2018). This has been stated in the Qur'an, Surah Al-Baqarah verse 275.

Based on this paragraph, Indonesia has implemented an Islamic monetary policy, which has been regulated in Bank Indonesia Regulation Number 16/12/PBI/2014 which 
took effect from July 24, 2014. This regulation issued to increase the effectiveness of Islamic monetary operations in the context of facing and anticipating economic development especially monetary. Islamic monetary operations are monetary policy implementation activities carried out by Bank Indonesia for monetary control through Islamic open market operations and Islamic standing facilities. Where the objective of this Islamic monetary operation is to achieve the operational target of monetary control in the form of adequate liquidity of IDR in Islamic banking, maintaining the balance of the real sector and the financial sector in the economy.

The growth of the Islamic financial system in Indonesia has shown encouraging developments and is quite increasing. This is indicated by the development of sharia economic activities and activities, the increase in Islamic financing, and quite a variety of Islamic financial market instruments. Internationally, Indonesia has great potential for the development of Islamic finance where Indonesia is ranked 2nd from the Islamic Finance Development Indicator (IFDI) 2020 (National Committee on Sharia Economics and Finance, 2020). The working mechanism of Islamic monetary operations to their impact on national economic development illustrates the transmission of Bank Indonesia monetary policy through changes in monetary instruments and operational targets that affect various economic variables.

In this study, through the variable of Bank Indonesia Sharia Certificates (SBIS), Islamic commercial banks and Islamic business units can assist Bank Indonesia in monetary control by absorbing liquidity from the public and placing excess funds at Bank Indonesia in IDR currency with the amount and short period and is expected to get a return on the placement of funds. Meanwhile, the provision of the Bank Indonesia Sharia Deposit Facility (FASBIS) for Islamic commercial banks and Islamic business units is used for monetary control of Sharia Standing Facilities to place excess funds at Bank Indonesia. As for the Sharia Interbank Money Market (PUAS), Islamic commercial banks and Islamic business units can place funds in interbank certificates. Total aggregate financing disbursed by banks, including Islamic commercial banks and Islamic business units, is here an intermediary target or target of Islamic monetary operations that have an impact on increasing activity in the real sector, especially in influencing the production of goods and services. This product is expected to increase the fulfilment of domestic and international needs through the export route so that it can increase Indonesia's foreign exchange and state income (Sukaman \& Kassim, 2010).

Referring to the research conducted by Rusydiana (2009), banking acts as an intermediary or intermediary institution to mobilize public funds in the form of deposits and distribute them in the form of financing to the public and the business world. The higher or lower the yield on the Islamic monetary instruments determined by Bank Indonesia will affect the financing to be distributed by Islamic banks. Seeing that Islamic 
banks also participate in monetary control which places excess liquidity in Islamic monetary instruments such as SBIS, FASBIS, and PUAS which will determine whether the distribution of financing is large. Furthermore, the dependent variable as $Y$ is the final target of the Islamic monetary operation policy carried out in Indonesia by Bank Indonesia.

This research is a study that discusses and provides alternative instruments that are appropriate and feasible to be applied to Islamic monetary operations carried out by Bank Indonesia as the central bank of the Indonesian state. As well as analyzing the influence of Islamic monetary operations from each alternative use of Islamic monetary instruments on Indonesia's economic growth that is appropriate and feasible to be applied to the conditions of the Indonesian state. This study adds more variables of Islamic monetary operating instruments and takes a longer period of research, namely from 2010 to 2020 so that the data trends are large and produce better data.

Based on previous studies, such as research conducted by Andarini and Widiastuti (2016), Bayuni and Srisusilawati (2018), Fitriani et al. (2012), Laksana (2020), Raseuky (2019), Syapriatama (2017), Wibowo and Mubarok (2018) who discuss and explain the research objects that are almost the same as each other, namely the Islamic monetary operation instrument. Previous research focused on discussing the influence of several Islamic monetary operating instruments (SBIS, FASBIS, PUAS) and aggregate financing, namely financing channeled by banks including Islamic banks and Islamic business units on Indonesia's economic growth for the period 2010-2020.

To see the impact of Islamic monetary operation policies in increasing Indonesia's economic growth, the authors would like to discuss several Islamic monetary operation instruments which include the variable of Bank Indonesia Syariah Certificates (SBIS), Bank Indonesia Sharia Deposit Facility (FASBIS), the Sharia Interbank Money Market (PUAS), and aggregate financing and their effect on economic growth as measured by economic growth indicators, namely gross domestic product (GDP) in the 2010 - 2020 period.

\section{LITERATURE REVIEW \\ Monetary Policy}

According to Naf'an (2014), monetary policy is an action taken by the monetary authority, namely Bank Indonesia as the central bank of the Indonesian state in regulating the money supply. Through monetary policy, Bank Indonesia as the monetary authority can increase, decrease, and maintain the money supply to maintain economic stability. The implementation of monetary policy by Bank Indonesia as the controlling

Published by University of Airlangga.

This is an open access article under the CC BY license (https://creativecommons.org/licenses/by-nc-sa/4.0/) 
holder of the money supply is carried out by setting monetary policy targets to be achieved and with what instruments these targets will be achieved.

According to Natsir (2014), monetary policy instruments are a means of controlling monetary policy used by Bank Indonesia as the monetary authority to influence the final operational targets set by Bank Indonesia. Some of the main instruments used in monetary policy to regulate the money supply include open market operation, discount rate, reserve requirement, and moral suasion.

\section{Islamic monetary operations}

Monetary operations are activities to implement Bank Indonesia's monetary policy in monetary control through Islamic open market operations and Islamic standing facilities (Laksana, 2020). Islamic monetary operations are aimed at achieving the operational target of Islamic monetary control to support the achievement of the final target of Bank Indonesia monetary policy. The operational target referred to in Islamic monetary control is in the form of adequate liquidity of IDR for Islamic banking or other variables stipulated by Bank Indonesia.

Islamic monetary instruments that can still be used from monetary application to regulate money in circulation are several monetary policy instruments in Islamic economics, including:

1. Regulation of the High-Powered Money

Bank Indonesia determines the optimal size of growth in high-powered money. A strong money supply must be consistent with growth in the real sector of the economy to support the growth process and avoid high inflation due to an oversupply of money.

2. Statutory Reserve Requirement Ratio

The reserve ratio may increase or decrease according to the dictates of monetary policy. If Bank Indonesia wants to control the money supply, it can increase the ratio, and if it wants to increase the money supply, it can decrease the ratio.

3. Credit Rationing

Bank Indonesia can control the direction and size of forward equity-based loans to certain sectors of the economy that serve both general and elective credit control functions.

4. Government Investment Certificate

Open market operations can be carried out by selling and buying some equity shares as a monetary policy note. As a substitute, the government issues an interest-free system called a Government Investment Certificate. 


\section{Islamic Open Market Operations}

According to Soemitra (2017), Islamic open market operations are money market transactions based on Islamic principles and provisions that are carried out by Bank Indonesia in conducting Islamic monetary operations. The achievement of the operational target is carried out by influencing the liquidity of Islamic banking through monetary contraction, namely reducing bank liquidity through Islamic monetary operations and monetary expansion, namely increasing bank liquidity through Islamic monetary operations. Open market operations are transaction activities in the money market carried out at the initiative of Bank Indonesia in order to reduce the volatility of $\mathrm{o} / \mathrm{n}$ PUAB interest rates. Islamic open market operations are usually carried out on a regular basis, but if this is necessary, Islamic open market operations can be carried out at any time. Islamic open market operations can be carried out in the following ways:

1. Issuance of SBIS (Bank Indonesia Sharia Certificate).

2. The sale and purchase of securities in IDR that complies with Islamic principles includes SBSN and other securities of high quality and easy to liquidate.

3. Absorption of funds without issuance of securities.

\section{Bank Indonesia Sharia Certificate}

Bank Indonesia Sharia Certificates are securities issued by Bank Indonesia with a short term in the IDR currency based on Islamic principles and regulations (Laksana, 2020). The certificate is issued as one of the instruments of Islamic open market operations in the context of monetary control carried out based on Islamic principles and regulations. Islamic commercial banks and Islamic business unit assist Bank Indonesia in monetary control by absorbing public liquidity and placing excess liquidity with Bank Indonesia. Bank Indonesia Sharia Certificates exists to maintain the stability of the IDR value through monetary control through Islamic open market operations. With the existence of Bank Indonesia Sharia Certificates, Islamic banks participate in placing their excess liquidity in Bank Indonesia Sharia Certificates at Bank Indonesia.

\section{Sharia Standing Facilities}

According to Latumaerissa (2017), Islamic standing facilities are facilities provided by Bank Indonesia to Islamic commercial banks and Islamic business units in the context of conducting Islamic monetary operations. Activities of providing IDR funds (financing facility) from Bank Indonesia to Sharia Commercial Banks or Sharia Business Units and placement of IDR funds (deposit facility) by Banks or Sharia Business Units at Bank Indonesia. The achievement of the operational target is carried out by influencing the 
liquidity of Islamic banking through monetary contraction, namely reducing bank liquidity through Islamic monetary operations and monetary expansion, namely increasing bank liquidity through Islamic monetary operations. Standing Facilities instrument is the provision of IDR funds (lending facility) from Bank Indonesia to Banks and placement of IDR funds (deposit facility) by Banks at Bank Indonesia in the context of establishing interest rate corridors in o/n PUAB. Sharia standing facilities are carried out through a non-auction mechanism. Sharia Standing Facilities are carried out in the following manner:

1. Provision of a deposit facility in the form of a Bank Indonesia Sharia Deposit Facility.

2. Provision of financing facilities in the form of repo securities in IDR.

\section{Bank Indonesia Sharia Deposit Facility}

Bank Indonesia Sharia Deposit Facility is a facility for Banks or Sharia Business Units used in monetary control of Sharia Standing Facilities to place funds in Bank Indonesia. The financing facilities here are made in the form of repo securities in IDR. Bank Indonesia Sharia Deposit Facility uses a Wadi'ah contract with a maximum period of 14 calendar days calculated from the transaction settlement date until the maturity date. Bank Indonesia Sharia Deposit Facility cannot be traded, cannot be pledged as collateral, and cannot be liquidated before maturity. Bank Indonesia Sharia Deposit Facility is present as a place for storing funds at Bank Indonesia where Bank Indonesia Sharia Deposit Facility can also assist financing to Islamic banks in accordance with the role of Bank Indonesia.

\section{Sharia Interbank Money Market}

Sharia Interbank Money Market based on Islamic principles, is a short-term interbank financial transaction activity, both in IDR and foreign currencies (Wibowo \& Mubarok, 2018). The development of the interbank money market can be carried out through various steps such as strategies for strengthening regulations, developing instruments, strengthening infrastructure and institutions, as well as expanding the issuer and investor base of interbank money market instruments based on sharia principles which are carried out in accordance with the needs of the Islamic banking industry. To deepen the deepening of the interbank money market based on Islamic principles, Bank Indonesia added instruments in the form of Interbank Mudharabah Investment Certificates (SIMA), Commodity Trading Certificates Based on Interbank Sharia Principles (SIKA), and Interbank Sharia Principles-Based Fund Management Certificates (SiPA), and Islamic repo transactions. Several parties that can carry out activities at Sharia Interbank Money Market for the placement of funds and receipt of 
these funds are Islamic commercial banks, Islamic business units, and conventional commercial banks. Sharia Interbank Money Market is present as a productive fund lending activity where there are underlying assets that are used as a source of rewards in achieving monetary control targets.

\section{Aggregate Financing}

Rivai and Arifin (2010) stated that financing is the distribution of funding provided by one party to another party in supporting activities or investments that have been planned, either alone or by an institution. The provision of facilities for providing funds to meet the needs of parties that constitute a unit deficit, which then the party must return the fund facilities that have been provided based on a period of time that has been determined between the two parties. Islamic financing, in general, is the activity of channeling funds to the public in the form of financing, as well as other financial service activities in total in a country. Financing as an intermediate target of monetary policy intended for liquidity injection in the direction of the economy.

The business activities carried out by Islamic finance companies include:

1. Sale and Purchase Financing, a financing in the form of providing goods through sale and purchase transactions in accordance with the Islamic financing agreement agreed by the parties, with the company's profits obtained from the margin.

2. Investment Financing, a financing in the form of providing capital for a certain period of time for productive business activities with profit sharing based on the profitsharing ratio principle in accordance with the Islamic financing agreement agreed upon by the parties.

3. Service Financing, is the provision/providing of services either in the form of providing benefits for an item, providing loans (bridging funds) and/or providing services with and/or without payment of fees (ujrah) in accordance with the Islamic financing agreement agreed by the parties.

\section{Economic Growth}

According to Kuznets (1995), economic growth is an increase in the long-term capacity of a country to produce various economic goods for its population which is determined by technological, institutional, and ideological adjustments (Wibowo \& Mubarok, 2018). Economic growth is an indicator of the quality of success of a country. In terms of macroeconomics, economic growth is an increase in the amount of gross domestic product (GDP). Gross domestic product shows the final value of goods and services produced by a country during a certain period. The indicator used to measure economic growth is the gross domestic product (GDP) (Ali, 2017) where it measures the 
total income of each community, both citizens and foreign citizens who produce the economy in that country, which is calculated from the value of goods and services produced in a certain year.

\section{Hypothesis Development}

\section{The Influence of Bank Indonesia Sharia Certificate on Indonesia's Economic Growth}

The Bank Indonesia Sharia Certificate (SBIS) is an Islamic monetary instrument used by Bank Indonesia to maintain and regulate the money supply in Islamic banking that will be used to channel financing. When Bank Indonesia raises SBIS fees, it will encourage Islamic banks to place their excess liquidity in SBIS. Likewise, on the other hand, when SBIS fees decrease, Islamic banking will increase the portion of financing that will be distributed to the public so that it can influence or increase business activities in the real sector and increase economic growth. With the use of Bank Indonesia Sharia Certificate as a certificate to place excess Islamic bank funds which can optimize the management of excess liquidity of Islamic banking. With this Bank Indonesia Sharia Certificate, Islamic banks also participate in monetary control by placing their excess liquidity in SBIS issued by Bank Indonesia. Bank Indonesia Sharia Certificate variable shows a negative shock which is responded by Gross Domestic Product. The increase in Bank Indonesia Sharia Certificate which is used to absorb excess liquidity causes a decrease in the rate of economic growth because liquidity is not channeled to the real sector. If you want to increase economic growth, you must reduce the issuance of Bank Indonesia Sharia Certificate so that more financing can be channeled. This is following what has been stated in research conducted by Laksana (2020), Syapriatama (2017), Wibowo and Mubarok (2018).

$H_{0}=S B I S$ does not have a direct influence on Indonesia's economic growth $H_{1}=S B I S$ has a direct influence on Indonesia's economic growth

\section{The Influence of Bank Indonesia Sharia Deposit Facility on Indonesia's Economic Growth}

The Bank Indonesia Sharia Deposit Facility (FASBIS) is an Islamic monetary instrument that functions as an absorbent tool to reduce excess liquidity from banks. When Bank Indonesia raises the Bank Indonesia Sharia Deposit Facility yield, the Islamic banking deposit facility at Bank Indonesia will increase and reduce the liquidity of Islamic banking, which has implications for declining economic growth. Likewise, on the other hand, when the Bank Indonesia Sharia Deposit Facility yields decrease, the Islamic banking deposits at Bank Indonesia will decrease so that it will increase economic growth. Bank Indonesia Sharia Deposit Facility as a facility provided by Bank Indonesia 
for Islamic banks in placing excess short-term funds. Bank Indonesia has the right to provide compensation for excess funds placed in Bank Indonesia Sharia Deposit Facility. This is because the Bank Indonesia Sharia Deposit Facility plays a very important role in monetary control for Bank Indonesia as well as a facility for placing excess short-term funds. Bank Indonesia Sharia Deposit Facility showed a positive shock which was responded by Gross Domestic Product. This result is different from the hypothesis, but that the increase in Bank Indonesia Sharia Deposit Facility used as a deposit container in placing excess banking liquidity does not cause a decrease in the projected economic growth rate through Gross Domestic Product. So, to increase the projected economic growth through Gross Domestic Product, the financing disbursed can be increased along with the increase in Bank Indonesia Sharia Deposit Facility. This is following what has been stated in research conducted by Raseuky (2019).

$H_{0}=F A S B I S$ does not have a direct influence on Indonesia's economic growth $\mathrm{H}_{2}=$ FASBIS has a direct influence on Indonesia's economic growth

\section{The Influence of Sharia Interbank Money Market on Indonesia's Economic Growth}

Sharia Interbank Money Market (PUAS) is a short-term interbank financial transaction activity based on Islamic principles in both IDR and foreign currencies to meet the absorption of excess liquidity in Islamic banking. The increase in Sharia Interbank Money Market yields will reduce the liquidity of Islamic banking, which in turn will reduce the financing capacity of Islamic banks and reduce economic growth. Meanwhile, a decrease in Sharia Interbank Money Market yields will increase the liquidity of Islamic banking, thereby increasing the distribution of Islamic banking financing to the real sector and increasing economic growth. Sharia Interbank Money Market as a means of borrowing productive funds that can be done if the borrower has underlying assets that can be used as a source of rewards. The use of Sharia Interbank Money Market is a feasible proposal because the provisions and returns are in accordance with sharia principles. With this Sharia Interbank Money Market, the excess funds in Islamic banks become productive and participates in monetary control. Sharia Interbank Money Market showed a positive shock which was responded by Gross Domestic Product. This result is different from the hypothesis, but that an increase in Sharia Interbank Money Market used to place funds in interbank certificates to manage banking liquidity does not cause a decrease in the rate of economic growth. So, to increase the projected economic growth through Gross Domestic Product, the additional financing channeled from the increase in Sharia Interbank Money Market yields can be

Published by University of Airlangga.

This is an open access article under the CC BY license (https://creativecommons.org/licenses/by-nc-sa/4.0/) 
increased as well. This is following what has been stated in research conducted by Laksana (2020) and Zaelina (2018).

$H_{0}=$ PUAS does not have a direct influence on Indonesia's economic growth

$\mathrm{H}_{3}=$ PUAS has a direct influence on Indonesia's economic growth

\section{The Influence of Aggregate Financing on Indonesia's Economic Growth}

Aggregate financing is financing channeled by the banking sector including Islamic commercial banks and Islamic business units to the public to finance real sector activities that will have an impact on increasing community productivity. This increase in community productivity can be through increasing the production of goods and services produced in a country and increasing people's income. Therefore, this financing is closely tied to the real sector. Funding channeled by banks to the public to finance real sector activities which will have an impact on increasing people's productivity through additional production of goods and services, increasing public income, and in turn increasing Gross Domestic Product (GDP) or economic growth. Financing that is channeled from the party providing funds to the party entitled to receive the funds based on the agreement and provisions must be channeled in accordance with what it should be. This, with properly channeled financing, will provide many benefits in building justice in a country and play an important role in the mechanism for controlling monetary policy. This financing is an intermediate target of monetary policy where financing is intended for liquidity injection or additional liquidity to the economy. Where the final monetary target will be achieved, namely economic growth. Aggregate financing showed a positive shock which was responded by Gross Domestic Product. This increase in the total distribution of aggregate financing will lead to an increase in the projected economic growth rate through GDP because the increase of this distribution will increase community productivity and real sector activities in producing goods and services. This is following what has been stated in research conducted by Syapriatama (2017); Wibowo and Mubarok (2018); Zaelina (2018).

$H_{0}=$ Aggregate Financing does not have a direct effect on Indonesia's economic growth $\mathrm{H}_{4}=$ Aggregate Financing has a direct influence on Indonesia's economic growth

\section{RESEARCH METHODS}

\section{Research Approach}

In this study, the authors used a quantitative research approach to determine the effect of independent variables on the dependent variable (Creswell, 2012). The quantitative research approach is also structured research and data processing to be 
generalized so that the effect of changes in an economic variable on other economic variables is obtained. This method is to answer and prove the effect of Islamic monetary operations, namely SBIS, FASBIS, PUAS, and Aggregate financing on Indonesia's economic growth for the 2010-2020 Period. The following is the empirical model of this research:

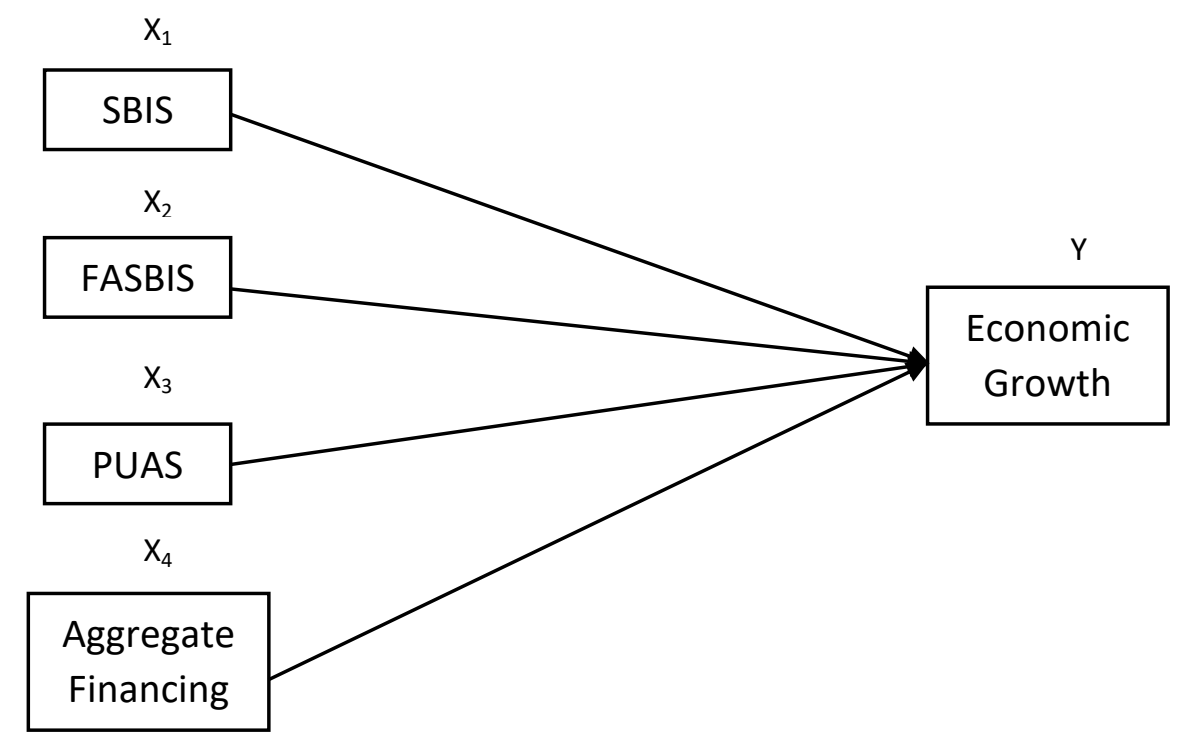

Figure 2 Research Empirical Model

From the model above, the independent variable which includes SBIS as $X_{1}$, FASBIS variable as $X_{2}$, and PUAS variable as $X_{3}$ are Islamic monetary operations carried out in Indonesia by Bank Indonesia which consist of operational targets for the monetary instrument of Islamic open market operations. In the independent variable aggregate financing as $\mathrm{X}_{4}$ is an intermediate target or target and an indicator of the Islamic monetary operation policy implemented by Bank Indonesia. Furthermore, the dependent variable economic growth as $Y$ is the final target of the Islamic monetary operation policy implemented in Indonesia by Bank Indonesia.

\section{Operational Definition of Variables}

Economic Growth is an increase in added value generated by all business units in a country or is the total value of the final goods and services produced by all economic units in a country. The GDP data used in this research is on the basis of constant price GDP data for the period January 2010 to December 2020 sourced from SEKI-BI to present 
economic and financial data to assist users in understanding Indonesia's economic and financial developments. On the basis of constant prices GDP data is available in a quarterly period which is expressed in billion IDR. Data is available within a monthly from January to December.

Bank Indonesia Sharia Certificate as a security based on Islamic principles issued by Bank Indonesia in the IDR currency where Islamic commercial banks and Islamic business units can place their excess short-term funds to get a return. The SBIS data used in this study is the SBIS data for the period January 2010 to December 2020 sourced from SEKI-BI. This SBIS data is available in a monthly period which is expressed as a percentage. Data is available within a monthly from January to December.

Bank Indonesia Syariah Deposit Facility is a deposit facility for Islamic commercial banks and Islamic business units at Bank Indonesia for Islamic monetary operations with a period of one working day. The FASBIS data used in this study is the FASBIS data for the period January 2010 to December 2020 which was sourced from SEKI-BI. This FASBIS data is available in a monthly period which is expressed as a percentage. Data is available within a monthly from January to December.

Sharia Interbank Money Market is a short-term interbank financial transaction based on Islamic principles, both in IDR and foreign currencies. Instruments in this PUAS transaction include SIMA, SIKA, SiPA, and Islamic repo transactions. The PUAS data used in this study is the PUAS data for the period January 2010 to December 2020 sourced from SEKI-BI. Sharia Interbank Money Market data is available in a monthly period which is expressed as a percentage. Data is available within a monthly from January to December.

Aggregate financing is all provision of funding based on an agreement or financing agreement between the bank and the domestic private sector to support planned investments, both alone and by institutions, as well as other financial service activities in total in a country. Aggregate financing data in this study is total aggregate banking financing data for the period January 2010 to December 2020 sourced from SEKI-BI. Aggregate financing data is available in a monthly period which is expressed in billions of IDR. Data is available within a monthly from January to December.

\section{Types and Sources of Data}

The type of data used in this study is secondary data, namely data that is not obtained directly, in the form of time-series data. Time-series data were used in this study from January 2010 to December 2020. The data source in this study used secondary data obtained from Indonesian Economic and Financial Statistics data published by Bank Indonesia (SEKI-BI) and the Central Bureau of Statistics (BPS) from January 2010 to December 2020. 


\section{Analysis Technique}

The data analysis technique in this study uses the Vector Autoregression (VAR) or Vector Error Correction Model (VECM) estimation method. According to Basuki (2018), VAR is a time series method that is widely used in research, especially research in the field of economics. This makes the use of the VAR estimation method easier to analyze because there is no need to distinguish which is the independent variable and which is the dependent variable. After all, all variables in the VAR estimation method can be considered as the dependent variable. If the data in the VAR estimation method is stationary at the level, then the VAR estimation method can be used. But if the data in the VAR estimation method is stationary in the First Difference, then in this case the VECM estimation method is used. Using VAR/VECM estimation model because the data used the time series data that describes economic fluctuations and explain the impact of monetary policy on developments in the real sector through a mechanism that generally does not have an immediate impact, usually requires a certain period of time (lag). These can be answered by the VAR/MECM estimation model as one of the most frequently used forms of macro-econometric models to look at the problem of economic fluctuations. The analytical tool used in this study uses the EViews software application which has advantages in terms of statistical tests related to time series data.

\section{RESULT AND ANALYSIS}

\section{Statistical Description of Bank Indonesia Sharia Certificate Variables}

Based on Bank Indonesia Regulation (PBI) Number 10/11/PBI/2008 concerning Bank Indonesia Sharia Certificates, Bank Indonesia Sharia Certificates, hereinafter referred to as SBIS, are short-term securities in IDR based on Islamic principles issued by Bank Indonesia as one of the Islamic monetary operation instruments in sharia open market operations. This SBIS can be issued in the framework of monetary control carried out following the principles and provisions of Islam.

Bank Indonesia Sharia Certificate in the early years, namely 2010 to 2016, experienced an increase and was quite stable, then in 2017 it experienced a very sharp decline followed by 2018 to 2020 with unstable increases and decreases. This shows that SBIS is indeed a step to enhance long-term Islamic monetary operations through the issuance of SBIS. Islamic commercial banks and Islamic business units are required to have liquidity and repay a certain amount of excess liquidity in the form of Islamic securities such as SBIS. The decline that occurred shows that the ownership of Islamic securities from Islamic commercial banks and Islamic business units in the form of SBIS is reduced.

Published by University of Airlangga.

This is an open access article under the CC BY license (https://creativecommons.org/licenses/by-nc-sa/4.0/) 


\section{Statistical Description of Bank Indonesia Syariah Deposit Facility Variables}

Based on Bank Indonesia Regulation Number 16/12/PBI/2014 concerning Islamic monetary operations, the Sharia Bank Deposit Facility, hereinafter referred to as FASBIS, is a facility for Islamic commercial banks and Islamic business units in the form of repo securities in IDR with Islamic provisions carried out by Bank Indonesia. This FASBIS can be used for monetary control and as one of the Islamic monetary operation instruments in Standing Facilities for placing funds at Bank Indonesia.

Bank Indonesia Syariah Deposit Facility in the early years, 2010 to 2011, experienced an increase, then experienced a sharp decline in 2012. The FASBIS trend has increased again and is quite stable from 2013 to 2015 and then decreased in 2016 to 2018 and again experienced an increase in 2019 but experienced a decline, which is quite sharp in 2020. It is shows that Islamic monetary operations to absorb liquidity were originally dominated by FASBIS in the early years. But over time there has been a shift to the use of SBIS (Bank Indonesia, 2019).

\section{Statistical Description of Sharia Interbank Money Market Variables}

Based on Bank Indonesia Regulation Number 22/9/PBI/2020 concerning the Interbank Money Market Based on Sharia Principles, the Interbank Money Market Based on Islamic principles, hereinafter referred to as PUAS, is a short-term interbank financial transaction activity based on Islamic principles both in IDR and in IDR. foreign exchange. Where in this money market there are several instruments, namely SIMA, SIKA, SiPA, and Islamic repo. This PUAS can be carried out in the framework of monetary control carried out following the principles and provisions of Islam.

Sharia Interbank Money Market in the early years experienced a sharp decline, namely in 2010, and experienced an unstable increase in 2011 to 2018. The PUAS trend then experienced a sharp decline from 2019 to 2020. This shows that the volume of PUAS transactions is quite high. Even though there is a decrease, it can still be overcome. Sharia Interbank Money Market transactions are dominated by the issuance of Interbank Mudharabah Investment Certificates (SIMA) and are dominated by tenors of less than one week.

\section{Statistical Description of Aggregate Financing Variables}

Based on Law Number 21 article 19 paragraph (1) and (2) of 2008 concerning Islamic Banking, both Islamic Banking which includes Islamic commercial banks and Islamic business units has the main function of collecting funds, hereinafter referred to as financing. Aggregate financing, in general, can be through the activities of channeling funds to the public in the form of financing and other financial service activities that are calculated in total in a country. 
Aggregate financing in the early years, namely 2010 to the end of 2020, continues to increase. This shows that current financing is very much needed to meet the financial needs of the sharia economy, one of which can be done by providing financing to both the government and the private sector based on Islam (Bank Indonesia, 2019). This financing can drive the flow of funds to keep them flowing to the wheels of the economy. It is expected that Islamic businesses that use Islamic financing can continue to increase to strengthen the economy in Indonesia.

\section{Statistical Description of Gross Domestic Product Variables}

Economic growth is an increase in the long-term capacity of a country to produce various economic goods to its population which is determined by technological, institutional, and ideological adjustments. Economic growth is an indicator of the quality of success of a country. In terms of macroeconomics, economic growth is an increase in the amount of Gross Domestic Product (GDP). Gross Domestic Product (GDP) shows the final value of goods and services produced by a country during a certain period.

Gross Domestic Product tends to decline and is unstable. It can be seen that from 2012 to 2013, the decline was slightly due to the weakening world economy, beset with uncertainty and declining export performance. However, economic growth has been supported more by domestic demand which remains strong. 2014 was also a year full of challenges because global economic conditions were quite bad, seen from the decline in economic growth. A very big decline was in 2020, where Indonesia's economic growth declined very sharply from 2019 due to the impact of the Covid-19 pandemic on economic activity and sales of goods or services in all sectors which decreased at different rates.

\section{Estimation Results and Verification of Hypotheses \\ Data Stationarity Test and Root Test}

The data stationarity test can be observed and tested using the Augmented Dickey-Fuller (ADF) method. The ADF test is the test most often used in the data stationarity test, which can see whether the data has a unit root in the model or not. The decision criterion at the significance level $(1-\alpha)$ is $100 \%, \mathrm{H}_{0}$ is rejected if the ADF statistic is smaller than the critical value at $\alpha$, or the $\mathrm{p}$-value is smaller than the significance value $\alpha$ or in other words, if $\mathrm{H}_{0}$ is rejected, then the data is stationary. If the data is stationary at the level, the VAR method estimation is used, but if the data is not stationary at the level, the VECM method estimation is used. The following is the table for the acquisition of the root test results:

Published by University of Airlangga.

This is an open access article under the CC BY license (https://creativecommons.org/licenses/by-nc-sa/4.0/) 


\begin{tabular}{|c|c|c|c|c|c|c|}
\hline \multirow{3}{*}{ Variable } & \multicolumn{5}{|c|}{$\begin{array}{c}\text { Table } 1 \\
\text { Root Test }\end{array}$} & \multirow{3}{*}{ Sig. 5\% } \\
\hline & \multicolumn{2}{|c|}{ Level } & \multirow{2}{*}{ Sig. $5 \%$} & \multicolumn{2}{|c|}{$1^{\text {st }}$ Difference } & \\
\hline & $\overline{A D F}$ & Prob. & & $\overline{A D F}$ & Prob. & \\
\hline SBIS & -2.324517 & 0.1659 & -2.884109 & -11.86942 & 0.0000 & -2.884109 \\
\hline FASBIS & -1.628314 & 0.4653 & -2.883753 & -6.909956 & 0.0000 & -2.883753 \\
\hline PUAS & -2.602939 & 0.0950 & -2.883930 & -12.27418 & 0.0000 & -2.883930 \\
\hline PA & -2.471684 & 0.1250 & -2.885863 & -5.008683 & 0.0000 & -2.886074 \\
\hline GDP & -1.427286 & 0.5670 & -2.884109 & -3.477045 & 0.0101 & -2.883930 \\
\hline
\end{tabular}

Source: Data Processed (2021)

Based on the output in Table 1 above, it can be seen that the ADF test statistical values of all variables, namely SBIS, FASBIS, PUAS, aggregate financing, and GDP, are not stationary at the basic level. Therefore, it is necessary to carry out the ADF test at the 1st difference level and obtain all variables namely SBIS, FASBIS, PUAS, aggregate financing, and this GDP is stationary. All these variables already have a consistent variety and can be tested at a later stage.

\section{Determination of Lag Length}

At this stage, selecting the optimum lag in the estimation of the VAR model is very important because it is useful for eliminating data autocorrelation. Determination using information criteria, namely Akaike Information Criteria (AIC), Schwarz Criteria $(\mathrm{SC})$, and Hannan Quinnon (HQ). The following is a table of lag results in this study:

\begin{tabular}{|c|c|c|c|c|c|c|}
\hline \multirow{2}{*}{ Variable } & \multirow{2}{*}{ Lag } & \multicolumn{5}{|c|}{ Criteria } \\
\hline & & LR & FPE & AIC & SC & HQ \\
\hline SBIS & 0 & NA & $1.60 \mathrm{e}+22$ & 65.31557 & 65.42930 & 65.36177 \\
\hline FASBIS & 1 & 1614.684 & $2.73 e+16$ & 52.03504 & 52.71737 & 52.31222 \\
\hline PUAS & 2 & 116.2660 & $1.46 e+16^{*}$ & 51.40937 & $52.66030 *$ & $51.91752 *$ \\
\hline AF & 3 & 43.69116 & $1.47 e+16$ & 51.40804 & 53.22758 & 52.14718 \\
\hline \multirow[t]{4}{*}{ GDP } & 4 & 39.15152 & $1.52 \mathrm{e}+16$ & 51.43116 & 53.81930 & 52.40128 \\
\hline & 5 & 44.22588 & $1.47 e+16$ & $51.38310^{*}$ & 54.33985 & 52.58420 \\
\hline & 6 & 27.69777 & $1.67 e+16$ & 51.48850 & 55.01385 & 52.92058 \\
\hline & 7 & $41.56090 *$ & $1.61 e+16$ & 51.41944 & 55.51340 & 53.08250 \\
\hline
\end{tabular}




\begin{tabular}{llllll}
\hline 8 & 24.09215 & $1.88 \mathrm{e}+16$ & 51.53240 & 56.19496 & 53.42644 \\
\hline Source: Data Processed (2021)
\end{tabular}

Based on the output in Table 2 above, it can be seen that the identification of this lag length determination uses the values of FPE, AIC, SC, and HQ which have the smallest or minimum value and the greatest or maximum LR value. In the results of the calculation, the recommended lag is the lag with the most asterisk $(*)$ code found in lag 2. This shows that the responses of each variable are interrelated for the next two periods.

\section{Cointegration Test}

At this stage, it is carried out to determine the long-term balance of the similarities in movement and the stability of the relationship between the variables in it. This cointegration test was carried out using the Johansen Cointegration Test method. Below are the results of the cointegration test processing with the Johansen Cointegration Test method:

Table 3

Cointegration Test

\begin{tabular}{ccccc}
\hline Number of CE(s) & Eigenvalue & Trace Statistic & $\mathbf{0 . 0 5}$ Critical Value & Prob. \\
\hline None* $^{*}$ & 0.247916 & 89.96743 & 69.81889 & 0.0006 \\
At most 1* & 0.153685 & 53.78422 & 47.85613 & 0.0125 \\
At most 2* & 0.112251 & 32.59247 & 29.79707 & 0.0232 \\
At most 3* & 0.093084 & 17.47105 & 15.49471 & 0.0249 \\
At most 4* & 0.039078 & 5.062446 & 3.841466 & 0.0244 \\
\hline
\end{tabular}

Source: Data Processed

Based on the table above, trace statistic and maximum eigenvalue values in the hypothesis None* are greater than the critical value with a significance level of $5 \%$. This means that $\mathrm{HO}$ which states that there is no cointegration is rejected and the alternative hypothesis which states that there is cointegration is accepted. Based on the above analysis, it can be seen that among the variables in this study, there is at least one cointegration at the $5 \%$ significance level. Therefore, the results of the cointegration test show that the variables have long-term stability and equilibrium relationship. 


\section{Granger Causality Test}

Table 4

Granger Causality Test

\begin{tabular}{lccc}
\hline \multicolumn{1}{c}{ Null Hypothesis } & Observation & F-statistic & Prob. \\
\hline SBIS does not Granger Cause GDP & 130 & 10.1970 & $8 . \mathrm{E}-05$ \\
GDP does not Granger Cause SBIS & & 3.30179 & 0.0401 \\
\hline FASBIS does not Granger Cause GDP & \multirow{2}{*}{130} & 2.01170 & 0.1381 \\
GDP does not Granger Cause FASBIS & & 1.14039 & 0.3230 \\
\hline PUAS does not Granger Cause GDP & \multirow{2}{*}{130} & 4.05452 & 0.0197 \\
GDP does not Granger Cause PUAS & & 0.96543 & 0.3836 \\
\hline AF does not Granger Cause GDP & \multirow{2}{*}{130} & 5.65803 & 0.0044 \\
GDP does not Granger Cause AF & & 1.36147 & 0.2601 \\
\hline
\end{tabular}

Source: Data Processed

From the results obtained, those who have a causal relationship are those that have a smaller probability value than alpha 0.05 so that later $\mathrm{HO}$ will be rejected, which means that a variable will affect other variables. From the Granger test above, we know the reciprocal relationship or causality of each variable as follows:

1. The SBIS variable has a significant value of $8 \times 10-5$, meaning that it is smaller than 0.05 , so it can be concluded that the variable has a significant relationship to the GDP variable.

2. The FASBIS variable obtained a significant value of 0.1381 , which means it is greater than 0.05 , so it can be concluded that the variable does not have a significant relationship to the GDP variable.

3. The PUAS variable obtained a significant value of 0.0197 , which means it is smaller than 0.05 , so it can be concluded that the variable has a significant relationship to the GDP variable.

4. The aggregate financing variable has a significant value of 0.0044 , meaning that it is smaller than 0.05 , so it can be concluded that the variable has a significant relationship to the GDP variable.

\section{Impulse Response Function Analysis}

In this study, Impulse Response Function (IRF) analysis can be used to see the effect of shocks from the SBIS variable on GDP, the effect of shocks from the FASBIS variable on GDP, the effect of shocks from the PUAS variable on GDP, and the effect of shocks from the aggregate financing variable for the next 10 months. The following is the data processing output from the Impulse Response Function analysis: 


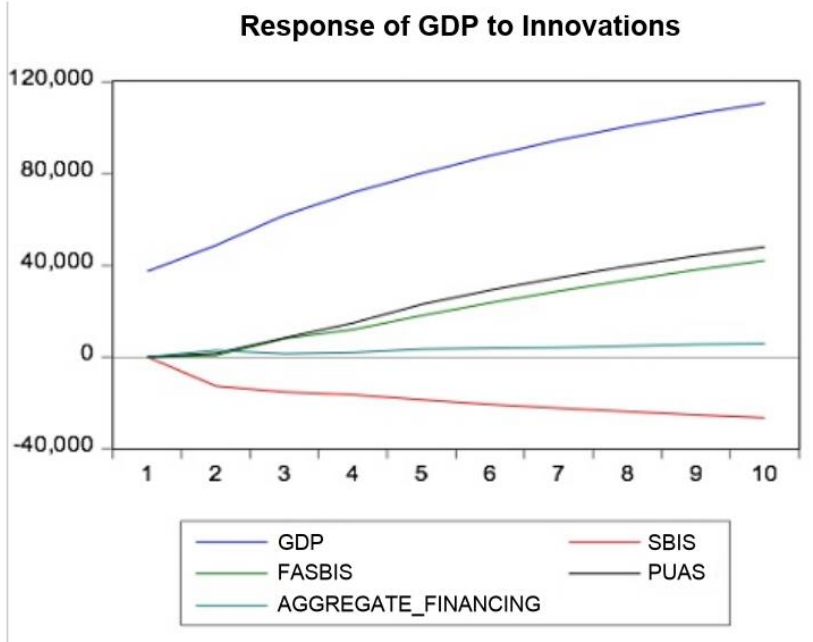

Figure 3. IRF Response

Source: Data Processed

Impulse Response Function analysis on GDP shows that shocks that occur in GDP, SBIS, FASBIS, PUAS, and aggregate financing have the effect of increasing GDP in the long run. The GDP variable, in the long run, affects the response of the GDP variable itself in the period 1 to 10 which experiences a positive shock to the increase in GDP itself. The SBIS variable shows a negative shock which GDP responds to in periods 1 to 10 . The FASBIS variable shows a positive shock which GDP responds to in periods 1 to 10 . The shock on the PUAS variable shows a positive shock in periods 1 to 10 which GDP responds to. The shock in the aggregate financing variable shows a positive shock and begins to stabilize in the period 5 to 10 .

\section{Forecast Error Variance Decomposition Analysis}

In this study, Forecast Error Variance Decomposition (FEVD) can be used to analyze which variable has the most dominant influence on the value of the GDP variable and to see the strengths and strengths of one variable in influencing other variables over a long period. The following is the data processing output from the Forecast Error Variance Decomposition analysis:

Table 5

FEVD Results

\begin{tabular}{cccccc}
\hline Period & GDP & SBIS & FASBIS & PUAS & AF \\
\hline $\mathbf{1}$ & 100.0000 & 0.000000 & 0.000000 & 0.000000 & 0.000000 \\
$\mathbf{2}$ & 95.58622 & 4.160859 & 0.008712 & 0.053822 & 0.190384 \\
$\mathbf{3}$ & 93.30430 & 4.934769 & 0.779727 & 0.867146 & 0.114059 \\
\hline
\end{tabular}




\begin{tabular}{llllll}
\hline $\mathbf{4}$ & 91.48067 & 4.876140 & 1.473874 & 2.079057 & 0.090260 \\
$\mathbf{5}$ & 88.88473 & 4.783228 & 2.456829 & 3.767094 & 0.108115 \\
$\mathbf{6}$ & 86.35934 & 4.708903 & 3.483388 & 5.327931 & 0.120434 \\
$\mathbf{7}$ & 84.08861 & 4.623297 & 4.477858 & 6.683826 & 0.126406 \\
$\mathbf{8}$ & 82.03746 & 4.542009 & 5.409068 & 7.975129 & 0.136337 \\
$\mathbf{9}$ & 80.20867 & 4.471322 & 6.269999 & 8.902938 & 0.147066 \\
$\mathbf{1 0}$ & 78.60235 & 4.410161 & 7.048952 & 9.782849 & 0.155684 \\
\hline
\end{tabular}

Source: Data Processed

The FEVD analysis on GDP shows that the largest contribution or effect that affects changes in GDP is GDP itself by $100 \%$ in period 1 and continues to decline in the following period. In the period after 1 , followed by an increase in the contribution or influence of the FASBIS and PUAS variables. Meanwhile, the contribution or influence of the SBIS variable has increased from period 1 to 3 but decreased in the period thereafter. The contribution or effect of the aggregate financing variable has increased from period 1 to 2 but decreased in the period thereafter. The biggest contribution that influenced the GDP variable were SBIS with a value of $4.93 \%$ in period 3, FASBIS with a value of $7.04 \%$ in period 10 , PUAS with a value of $9.78 \%$ in period 10 , and aggregate financing with a value of $0.19 \%$ in period 10 period 2 .

\section{Interpretation of Results and Discussion The Influence of SBIS on Economic Growth}

From the results of the analysis of the VECM estimation method that has been carried out, this SBIS rate of return has a small and insignificant effect for the short-term period but provides a large and significant response to GDP in the long term. In the IRF analysis, it is explained that the SBIS variable shows a negative shock which GDP responds to. The increase in SBIS, which is used to absorb excess liquidity, causes a decrease in the rate of economic growth because liquidity is not distributed to the real sector. If you want to increase economic growth, you must reduce the issuance of SBIS so that more financing is channeled.

This research supports the research that has been conducted by Laksana (2020), Syapriatama (2017), Wibowo and Mubarok (2018). The study also explained that the SBIS showed a negative shock, which means that any increase in the SBIS rate of return will reduce the projected rate of economic growth through GDP. In the FEVD analysis, it is explained that the composition of the SBIS value in its contribution to GDP is the highest, namely $4.93 \%$. It can be seen from this that high or low SBIS interest rates influence changes in decisions and actions of Islamic commercial banks and Islamic 
business units, both used to channel more financing or invest excess liquidity in SBIS instruments which will affect projected economic growth. through PDB. In the FEVD analysis, it is explained that the composition of the SBIS value in its contribution to GDP is the highest, namely $4.93 \%$. It can be seen from this that high or low SBIS interest rates influence changes in decisions and actions of Islamic commercial banks and Islamic business units, both used to channel more financing or invest excess liquidity in SBIS instruments which will affect projected economic growth through PDB. In the FEVD analysis, it is explained that the composition of the SBIS value in its contribution to GDP is the highest, namely $4.93 \%$. It can be seen from this that high or low SBIS interest rates influence changes in decisions and actions of Islamic commercial banks and Islamic business units, both used to channel more financing or invest excess liquidity in SBIS instruments which will affect projected economic growth through PDB.

\section{The Influence of FASBIS on Economic Growth}

From the results of the analysis of the VECM estimation method that has been carried out, FASBIS has a large and significant effect for the short-term period and provides an increasingly positive and significant response to GDP in the long term. In the IRF analysis, it is explained that the FASBIS variable shows a positive shock which GDP responds to. This result is different from the hypothesis, but that the increase in FASBIS which is used as a container for savings in placing excess liquidity in the banking sector does not cause a decrease in the projected rate of economic growth through GDP. So, to increase the projected economic growth through GDP, then the channeled financing can be increased along with the increase in FASBIS. Where this research is different from the research conducted by Raseuky (2019) which states that FASBIS has a negative shock effect because an increase in the number of FASBIS will reduce the projected rate of economic growth through GDP. In the FEVD analysis, it is explained that the composition of the FASBIS value in its contribution to GDP is the highest, namely $7.04 \%$. It can be seen from this that FASBIS influences changes in decisions and actions of Islamic commercial banks and Islamic business units, both used to channel financing or to invest excess funds in FASBIS instruments which will affect projected economic growth through GDP.

\section{The Influence of PUAS on Economic Growth}

From the results of the analysis of the VECM estimation method that has been carried out, the PUAS rate of return has a small and insignificant effect for the shortterm period but provides a large and significant response to GDP in the long term. In the IRF analysis, it is explained that the PUAS variable shows a positive shock which GDP 
responds to. This result is different from the hypothesis, but that the increase in PUAS which is used to place funds in interbank certificates to manage banking liquidity does not cause a decrease in the rate of economic growth. So, to increase the projected economic growth through GDP, the additional financing channeled from the increase in PUAS yields can also be increased. Where this research is different from the research conducted by Laksana (2020) and Zaelina (2018) which stated that PUAS has a negative shock effect because the increase in PUAS yields makes Islamic banks more interested in investing in PUAS instruments so that it will affect the amount of financing they increase the projected economic growth through GDP. In the FEVD analysis, it is explained that the composition of the PUAS value in its contribution to GDP is the highest, namely $9.78 \%$.

\section{The Influence of Aggregate Financing on Economic Growth}

From the results of the analysis of the VECM estimation method that has been carried out, the level of aggregate financing has a large and significant effect for the short-term period and provides an increasingly positive and significant response to GDP in the long term. In the IRF analysis, it is explained that the variable shows a positive shock which GDP responds to. Aggregate financing serves as an intermediary target to realize monetary targets related to the provision of funds to the public in the form of financing and financial services activities to increase real sector activities, especially in the production of goods or services. This increase in the total distribution of aggregate financing will lead to an increase in the rate of economic growth projected through GDP because the increase in this distribution will increase the productivity of society and the activities of the real sector in producing goods and services. Where this research supports the research that has been conducted by Syapriatama (2017); Wibowo and Mubarok (2018); Zaelina (2018). In the FEVD analysis, it is explained that the composition of the value of aggregate financing in its contribution to GDP is the highest at $0.19 \%$. It can be seen from this that much or not of the total aggregate financing that can be distributed to the community will provide a large contribution which will ultimately affect economic growth.

\section{CONCLUSION}

The findings in this study were obtained based on the SBIS, FASBIS, and PUAS variables which were the instruments of Islamic monetary operations carried out through sharia open market operations and sharia standing facilities. As well as aggregate financing which is the target of intermediaries to realize monetary targets. SBIS, FASBIS, and PUAS are used to regulate excess liquidity of Islamic commercial banks and Islamic business units that will optimize monetary control. Aggregate financing 
associated with providing funds in the form of financing and financial services activities to increase real sector activity will also optimize monetary control.

The effect of Islamic monetary operations (SBIS, FASBIS, PUAS) and aggregate financing on economic growth in Indonesia needs to be carried out more deeply to enrich literature studies on the problems and impacts of implementing Islamic monetary operations on economic growth. It can contribute to the development of theories and knowledge related to the field of Islamic monetary. Continuous research can be used as input and consideration in policy making that will be determined in optimizing Islamic monetary policy in Indonesia. In this research process, there are some of the limitations experienced by the author. The variables of Islamic monetary operations instruments in this research are still not widely used to implement monetary policy so that they are still not varied and for SBIS variable data in 2010 is still incomplete because in that year SBIS did not exist and still used SWBI (Bank Indonesia Wadi'ah Certificate).

\section{ACKNOWLEDGEMENT}

This research is part of the thesis by the author and under supervised by the coauthor. Thank you to our parents, family, and all academic members of the Faculty of Economics and Business, University of Airlangga, who have full support in working on this research.

\section{REFERENCES}

Ali, I. H. (2017). Ekonomi Makro. Kencana Prenadamedia.

Andarini, M. A., \& Widiastuti, T. (2016). The Influence of SBIS and PUAS on Inflation Rate Through Sharia Monetary Operations in the 2011-2015 Period [Pengaruh SBIS dan PUAS terhadap Tingkat Inflasi melalui Operasi Moneter Syariah pada Periode 2011-2015]. Jurnal Ekonomi Syariah Teori Dan Terapan, 3(6). https://doi.org/10.20473/vol3iss20166pp474-489

Basuki, A. T. (2018). Application of VAR and VECM Models in Economics. Muhammadiyah University Publishing.

Bayuni, E. M., \& Srisusilawati, P. (2018). Contribution of Sharia Monetary Instruments to Inflation Control in Indonesia [Kontribusi Instrumen Moneter Syariah terhadap Pengendalian Inflasi di Indonesia]. Amwaluna: Jurnal Ekonomi Dan Keuangan Syariah, 2(1), 18-38.

Creswell, J. W. (2012). Research Design Approach to Qualotative, Quantitative, and Mixed Methods (3rd ed.). Sage Publications.

Fitriani, Y., Aziz, R. M., \& Amalia, F. (2012). Linkage of Sharia Monetary Indicators to Gross Domestic Income [Keterkaitan Indikator Moneter Syariah terhadap Pendapatan Domestik Bruto]. Signifikan: Jurnal Ilmu Ekonomi, 1(1). https://doi.org/10.15408/sjie.v1i1.2595 
Juhro, S. M., Darsono, D., \& Sakti, A. (2018). Kebijakan Moneter Syariah dalam Sistem Keuangan Ganda Teori dan Praktik. Tazkia Publishing.

Kuznets, S. (1995). Economic Growth and Income Inequality. The American Economic Review, 45(1), 1-28. https://www.jstor.org/stable/1811581

Laksana, K. U. (2020). Analysis of the Effectiveness of Sharia Monetary Policy Transmission on Inflation and GDP [Analisis Efektivitas Transmisi Kebijakan Moneter Syariah terhadap Inflasi dan GDP]. IAIN Salatiga.

Latumaerissa, L. (2017). Bank dan Lembaga Keuagan Lain: Teori dan Kebijakan. Mitra Wacana Media.

Naf'an, N. (2014). Ekonomi Makro: Tinjauan Ekonomi Syariah. Graha Ilmu.

Natsir, N. (2014). Ekonomi Moneter dan Perbankan Sentral. Mitra Wacana Media.

Raseuky, M. (2019). Pengaruh Instrumen Operasi Moneter Syariah Terhadap Pertumbuhan Ekonomi Di Indonesia Periode 2014-2018 [Universitas Islam Negeri Sumatera Utara Medan]. http://repository.uinsu.ac.id/6599/

Rivai, V., \& Arifin, A. (2010). Islamic Banking: Sebuah Teori, Konsep, dan Aplikasi. Bumi Aksara.

Rusydiana, A. S. (2009). Hubungan Perdagangan Internasional dan Industri Keuangan Syariah Di Indonesia. Tazkia Islamic Finance and Business Review, 4(1), 47-60. https://tifbr-tazkia.org/index.php/TIFBR/article/view/30

Soemitra, A. (2017). Bank \& Lembaga Keuangan Syariah (2nd ed.). Prenada Media.

Sukaman, R., \& Kassim, S. H. (2010). Roles of the Islamic Banks in the Mtransmission Process in Malaysia. International Journal of Islamic and Middle Eastern Finance and Management, 3(1), 7-19. https://doi.org/10.1108/17538391011033834

Syapriatama, I. (2017). Transmisi Kebijakan Moneter Jalur Pembiayaan Bank Syariah di Indonesia. IQTISHADUNA, 8(2), 1-11.

Twinoburyo, E. N., \& Odhiambo, N. M. (2018). Monetary Policy and Economic Growth: A Review of International Literature. Journal of Central Banking Theory and Practice, 7(2), 123-137. https://doi.org/10.2478/jcbtp-2018-0015

Wibowo, M. G., \& Mubarok, A. (2018). Analisis Efektivitas Transmisi Moneter Ganda Terhadap Pertumbuhan Ekonomi Indonesia. Jurnal Ekonomi Pembangunan, 25(2), 127-139. https://doi.org/10.14203/jep.25.2.2017.127-139

Zaelina, F. (2018). Mekanisme Transmisi Kebijakan Moneter Syariah. Indonesian Interdisciplinary Journal of Sharia Economcis, 1(1), 19-30. https://doi.org/10.31538/iijse.v1i1.69 